\title{
スマートメータによる省エネ実験*
}

平沼賢次 ${ }^{* 1}$, 川名優孝 ${ }^{* 2}$, 刑部真弘 ${ }^{* 3}$ 木船弘康 ${ }^{* 1}$, 毛利邦彦 ${ }^{* 2}$, 犬飼和具 ${ }^{* 4}$

\section{Energy Saving Experiment by Smart Meter}

\author{
Kenji HIRANUMA *1, Masataka KAWANA, Masahiro OSAKABE \\ Hiroyasu KIFUNE, Kunihiko MOURI and Kazutomo INUKAI
}

${ }^{*}$ Tokyo Univ. of Marine Science \& Technology, Fac. of Marine Engineering

This paper describes on the energy saving experiment by using the smart meter. In Japan, last summer, the power shortage was concerned and the limited use of electric power had been issued from the government. We constructed display system of the electric power consumption of Tokyo University of Marine Science and Technology (TUMSAT) on the web. This system could provide the average power usage during 10 minutes to promote the energy saving actions of each consumer. From the energy saving experiment in our university, it was found that the display on web was significantly effective to suppress the consumption of electric power without the compulsory cut off.

Key Words: Smart Grid, Smart Meter, Energy Saving Action, TUMSAT

\section{1. 緒言}

現在の電力システムで採用されている「同時同容量」は，ユーザー側の需要に合うように電力供給を行う仕組 みである. 例えば，需要および供給の相違は，30 分で3\%以内にしなければならない，電力会社が,これを守るこ とによって電力の安定供給が行われてきた. ところが，この「同時同容量」というシステムは，電力が不足して もユーザーは使いたいだけ使い, 電力会社はそれに追従して発電するという非常に危険なものである.このため, 東日本大震災直後の電力不足時には計画停電を行わざるを得なかった．本来は，人工呼吸器を使っている家庭や 交通信号等を考えれば，計画停電という無差別停電は行うべきではない. 電力会社自身も，需給ひっぱく時に使 用抑制をする条件で通常時電力料金を低くしている契約者を設定していたはずであるが,うまく機能しなかった.

さらに，この計画停電では，電力卸売り事業者（IPP）発電の送電もカットした. 例えば，商社等が発電所を持 ち電力会社の送電線を利用して契約ユーザーに電力を売っているのである. 電力卸売り事業者は, ユーザーとの 間で電力供給契約をしており，それが電力会社の都合で履行できなくなったのである. これは，電力に関して自 由な発想に基づく事業が制限されることを示している.

また，計画停電後に迎えた昨年の夏は，電力不足が予想されたため節電への取り組みが強く奨励された.

$500 \mathrm{~kW}$ 以上の大口需要家に対して電気事業法第 27 条に基づく電力使用制限により，前年比 $15 \%$ の削減が求め られた。東京海洋大学越中島キャンパスではその該当となる事から，スマートメータを活用した節電実験に取り 組むことにした．複数の教職員および学生によって構成されるキャンパス全体を対象としたスマートメータによ る節電は，電力不足時において電力を安定供給する重要な要素になると考えられる.

現在，スマートグリッド(1)(2)が注目され，多くの企業からシステムが提案されている. しかし，その多くは大 規模，複雑化しており，どれもがほぼ類似したシステムと言っても過言ではない. また，導入をするためには法

* 原稿受付 2012 年 8 月 29 日

*1 東京海洋大学（干135-0016 東京都江東区越中島 2-1-6)

*2 正員, 東京海洋大学

*3 正員, フェロー, 東京海洋大学

*4 東洋電機製造 (株) （下103-0028 東京都中央区八重洲 1-4-16）

E-mail: m-kawana@kaiyodai.ac.jp 
律や規制, 既存のシステムとの整合性等の課題解決と多額の資金が必要となる．まずは，この様な大規模のシス テムを導入する前に, 比較的安価に普及しや寸いシンプルな方法で, 出来ることから取り組むことが必要である. いくら優れたシステムを描いても，実際に導入が出来なければ意味がない.

本論文では，比較的導入がしやすく消費者が能動的に省エネルギー活動に参加する方法を提案し，スマートメ ータを活用した電力の見える化による省エネルギー実験とその結果について述べる.

\section{2. スマートメータによる電カの見える化}

\section{$2 \cdot 1$ 実験の目的}

本実験の目的は，本学越中島キャンパスを対象に，教職員，学生が電力状況を把握する事により節電が可能か を検討する事にある．特長は大規模なハードや複雑なソフトに依存せずにエネルギー行動を促すことである.

本実験では下記 3 点に注目し実施した.

(1)自らの節電行動の貢献度を反映しや寸い適切なレスポンスによる電力の見える化.

(2)行動喚起および簡単な指針を示すことによる節電行動の促進.

(3)簡便で安価なシステム構成.

大学というある程度人口密度があり, 限られた区域内のコミュニティにおいて構成員が自ら電力を融通しあう ことを期待した．電力消費の情報公開はキャンパス全体の電力量のみとしたところが最大の特長である.

\section{$2 \cdot 2$ 実験装置}

本学越中島キャンパスの電力消費を把握するために, スマートメータを設置した．本実験ではキャンパス内の 全ての受電端にスマートメータを装着するのではなく, 消費者の行動が反映されやすい空調や電灯が多く使用さ れる場所を選定し設置した，キャンパス全体の電力は，上位の受電端からパルス信号を取得して計測した．本学 では, 1999 年にスマートメータを設置し計測した経験があるが, 当時は全て有線でデータを取得するシステム のため設置場所に制限があり，更に複雑な配線工事が必要であった，そのため，簡便に設置可能な装置を調查し， センサ部とデータ収集部のワイヤレス化を実現した東洋電機製造社製の機器(2)を選定した. 既存の電気設備に設 置しや寸いという特長があり，今後汎用的に用いる事が可能であると考えられる.

同社のスマートメータには電力消費の傾向を知るために付属されている専用のソフトウェアがある. グラフや レポートの作成など充実したものであるが, 各端末へのインストールが必要となり, 教職員がいつでも確認が出 来る環境を構成するには大変な手間と費用がかかる. また, 携帯電話端末では見る事が出来ない. そのため, 図 1 で示すように, センサから収集したデータを別のサーバに転送して Linux で専用に開発したソフトウェアで処 理をしてイーサネットを通じてデータの公開を行うシステムを構築した.

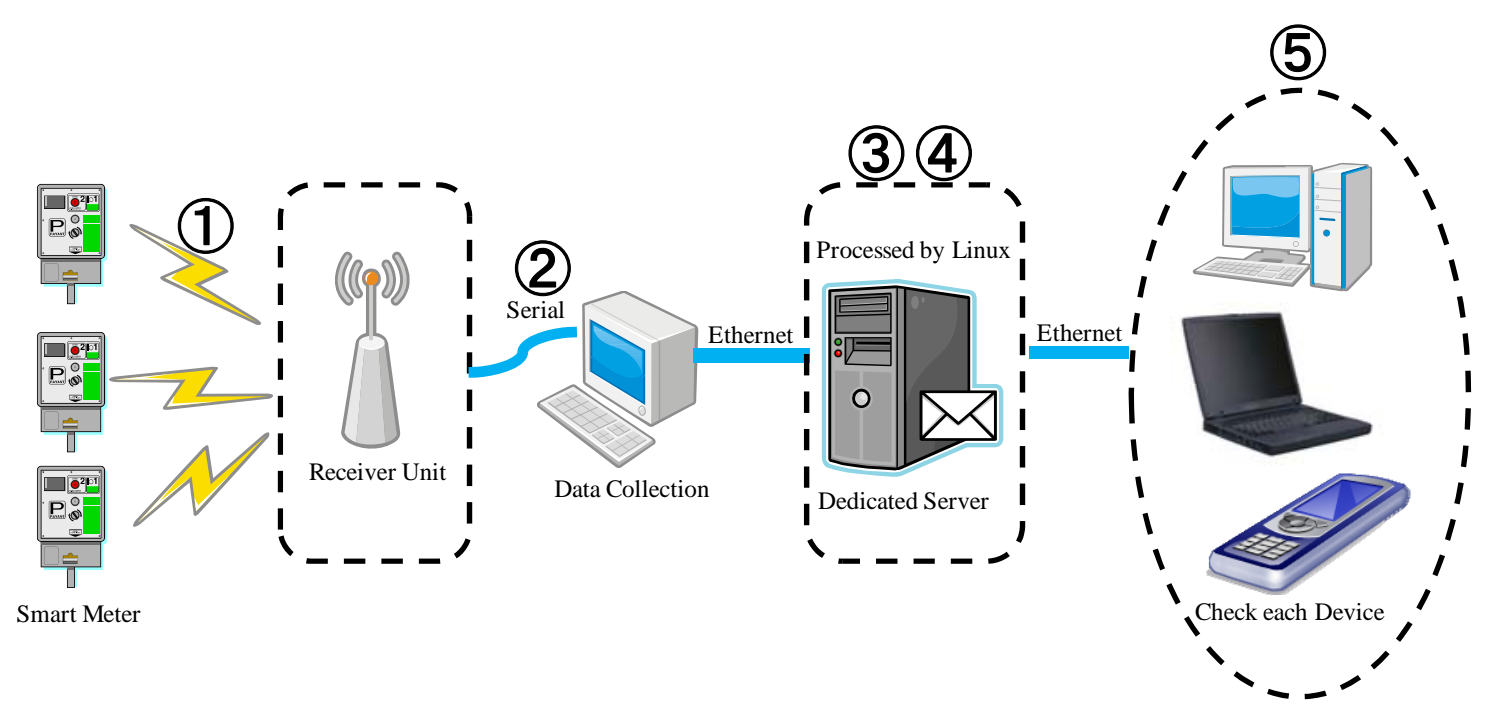

Fig.1 Wireless Smart Meter System by TUMSAT 


\section{$2 \cdot 3$ 処理システム}

本システムは，セキュリティが高いという特長を持ち安定的な稼働が期待される Linux で開発をおこなった. 下記に示すような処理により見える化を実現している.

(1)センサから取得したデータは，無線で受信ユニットに送信される.

(2)受信ユニットではデータを保持する機能が付加されていないため, シリアルを通じて東洋電機社製のソフトが インストールされた Windows コンピュータにデータを収集しファイルに保存する.

(3)本学に設置した専用サーバからイーサネットを通じて Windows コンピュータからデータをダウンロードする. (4)専用サーバでは, Linux で構成されたシステムにより, ダウンロードデータの日付変換, 1 分毎に補完処理等を 実行する.

(5)グラフを作成し，Web サーバに保管しWeb 配信する.

本システムは，将来ユーザーや計測対象，データ量が増加することを予め考慮し，拡張性を有していることか ら小規模から大規模まで対応が可能である.

\section{$2 \cdot 4$ 電力消費状況の見える化}

東日本大震災後 Yahoo 等では東京電力管内における電力消費のグラフを Web で表示し節電を呼び掛けた. 地域 全体の電力状況はおおよそ把握出来るが 1 時間ごとの平均使用電力であり, また, 消費者が節電行動を実行して もあまりに広範囲のため, 自らの行動に対する貢献度が見えにくい. したがって, ある限られた範囲のコミュニ ティにおける電力消費データを取得し, 適切なレスポンスによる見える化が肝要である. 本実験では, 10 分ごと に補完した電力の消費状況を表示している．これが，例えば1分おきではグラフがスパイク状となってしまい， 傾向が分かりにくい表示となる. 今回の実験では，大学というコミュニティにおいて節電行動を促すことのでき る見える化を実現するため, Web 上での表示はシンプルな棒グラフとした. また, 節電目標の最大值である $694 \mathrm{~kW}$ 以上をイエローゾーン, キャンパスの契約電力量をレッドゾーンで示し, 危機感を喚起することにした. 教職員, 学生に公開した画面を図 2 に示寸.

今後，商業施設や住宅地，公的施設等において展開する場合，建物の設備，地域性，コミュニティの特長等か ら, 状況に合致した処理レスポンスを選択することが必要であると考えられる，そのため計測時間間隔を任意に 変化する事を可能にするなどの工夫が必要である．また，本実験に用いた $315 \mathrm{MHz}$ 帯での無線データ転送は 10 秒間隔である事が電波法により定められており, 計測点はレスポンスを考慮し最適数を求めることが必要である.

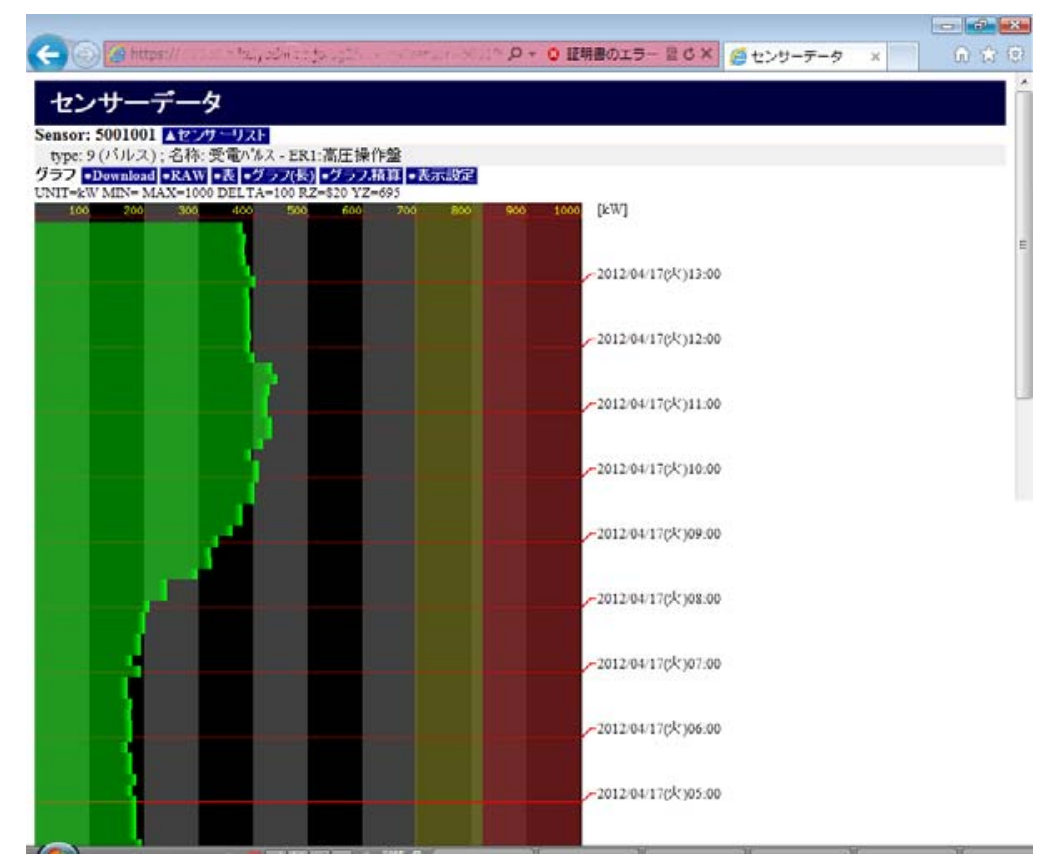

Fig.2 Display on the Web 


\section{$2 \cdot 5$ 実験方法}

実験は，2011年 6 月 27 日の昼休みから開始した，以降は継続して電力の抑制について喚起を行い，電力使用 制限の早期緩和が宣言された 9 月 9 日まで実施した. 実験の開始は教職員の場合は会議等で協力を求め，事前に 一斉メールを送信し予告した．図 2 のグラフを随時把握してもらうためにURL を公開し，携帯電話端末でも確 認が容易に出来るよう，QR コードを学内の HP に表示した. 更に電力使用の状況がイエローゾーンに近づいた際 の具体的な行動について下記の 4 点を示し推奨した.

(1)照明の消灯.

(2)空調の設定温度を通常使用状態より $2^{\circ} \mathrm{C}$ 上げる.

(3)パソコンをスタンバイ状態にして充電は停止する.

(4)大電力装置の使用を控える.

いずれも，あまり無理をしないでとれる行動である．しかし，来客や体調が悪く空調がないと困る等の場合は 自らの判断で節電行動に参加をしなくても良いこととした. 支障のない範囲で節電行動に協力出来る構成員が上 記 4 点に基づいて実行する．個人での節電行動には限界があるが，コミュニティ全体の状況を見て其々が節電に 協力することによる相乗効果は大きい.

学生に対しては事前の周知をしなかったが，昼休みに構内放送をすることにより喚起を図った．また，教職員 の節電行動を模範に学生は自ら行動した. 本学では, 電気自動車, 電池推進船用に 2 台の急速充電器が設置され ているが, 昼間における充電は大電力を使用するため, 早朝または夜間にシフトをするなどの調整をおこなった.

\section{$2 \cdot 6$ 実験結果}

図 3 に 6 月 27 日と 7 月 8 日における無次元電力消費量を示す. 各時刻の電力消費量を, 午後 12 時を基準とし た電力消費量で割って無次元化した. 6 月 27 日 12〜13 時には節電幅を調べるため上記 4 点の節電行動を一斉に とるよう構成員に指示したが， 7 月 8 日にはしていない. 出勤時間や授業が開始される午前 9 時以降は活動が活 発になるため電力の消費は上昇し続ける. 両日とも同様の傾向であった. 午後 12〜13 時に注目をすると, 6 月 27 日においては指示した節電行動により, 無次元電力需要が 10 ポイント程度下がった. すなわち, 一斉に行う節電 行動により 10 ポイント程度の電力削減が可能であることが確認された。

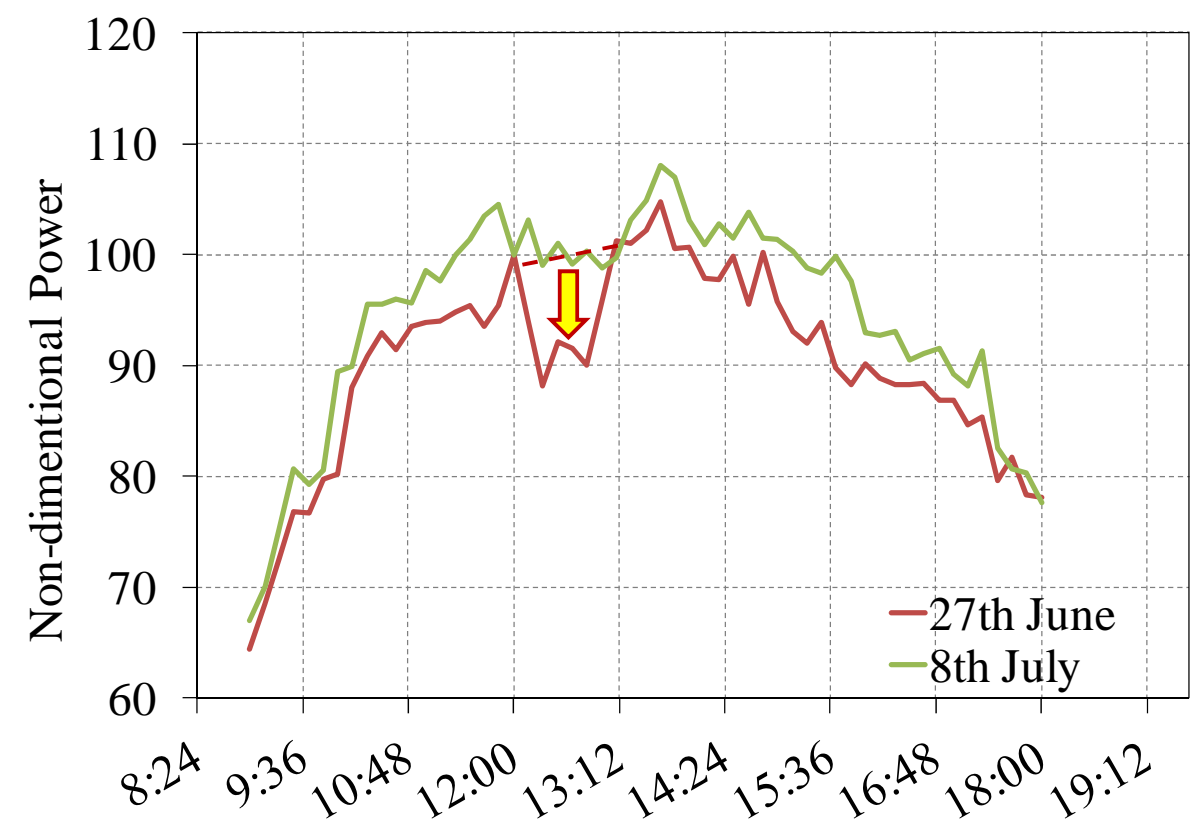

Fig.3 Non-dimensional electric demand on June 27 and July 8

図 4 に 7 月 11 日の電力消費の推移を示す. 昼休久時間は節電の奨励により減少傾向を示す. しかし, 空調を停 止すると時間の経過により室温が上昇するため, 再び増加傾向を示す. 13 時以降は電力消費量が増え続け, 節電 
目標值である $700 \mathrm{~kW}$ に近づくと省エネルギー行動がおこる，そのため，再び減少傾向を示すことから，構成員は 節電行動をしていることがわかる．その結果，電力使用量を前年同月比で比較すると， 7 月 $16 \% ， 8$ 月 $22.6 \% ， の$ 低減を達成することが出来た. 更に 9 月 9 日に電力使用制限の早期緩和が宣言されたが，その後も節電行動を自 主的に実施する構成員が多く，9月においても $23.8 \% の$ 節電を達成している．この結果から，コンピュータによ る電気機器の強制的な制御，極端な我慢の強要は必要ないことがわかった。

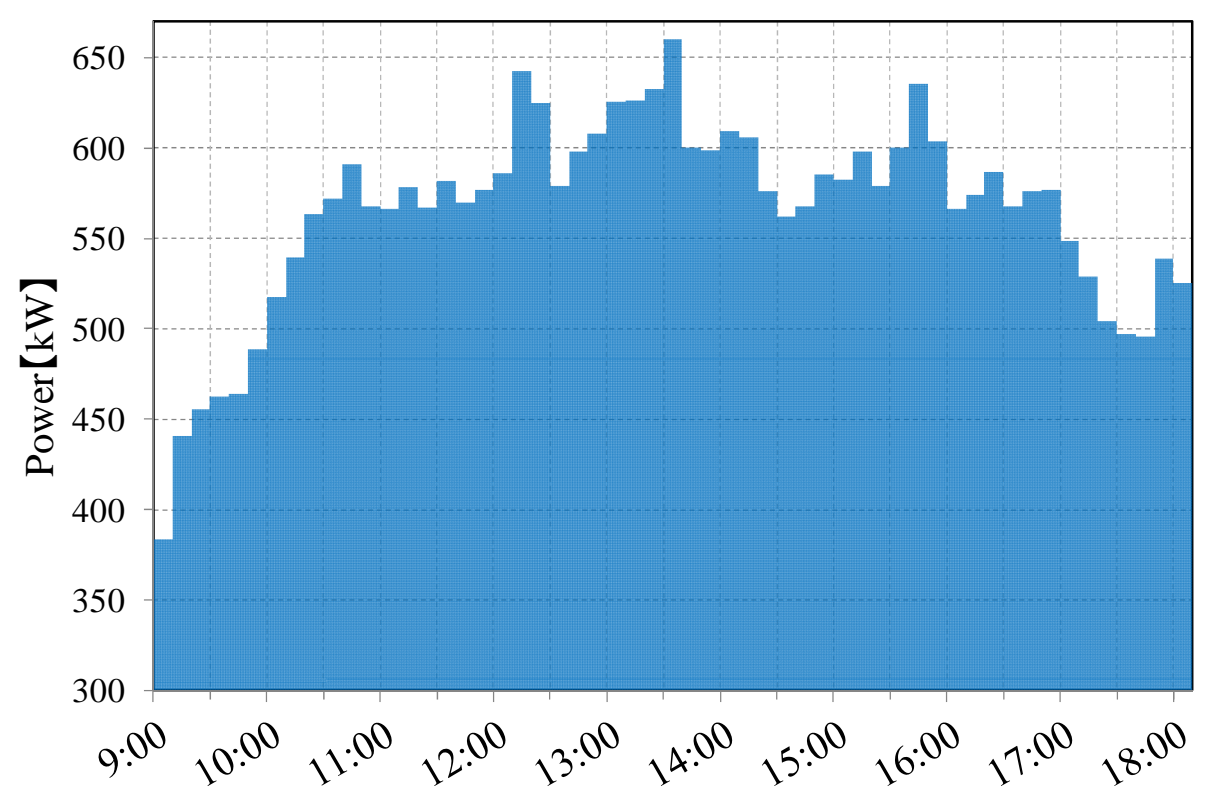

Fig.4 Transient electric demand on July 11

\section{3. 結言}

本実験の結果から，電力消費状況の把握と具体的な節電行動を示寸事で消費者の節電行動を促し，電力使用の 抑制が可能である事がわかった，消費者は状況の把握により相互協力し，結果として必要な場所では空調等が使 用可能となり，節電をする状況下にあっても省エネと快適な環境を両立出来た.

これは, コミュニティ全体の電力消費量の見える化と共に, 自らの節電行動に対する結果を, 適切なレスポン スで伝えることにより, 構成員の参加意欲と節電行動のモチベーションを喚起したことから達成できた. このこ とから, 強制的な計画停電をしなくても電力抑制ができる可能性が示唆された. 今後は, 一般住宅の集合地域, マンション，商業施設，アミューズメント施設等様々な形態のコミュニティで実験を実施し，節電行動を促しや すいコミュニティの規模や電力量の消費状況を把握する必要がある. これらの分析から, 変動しやすい再生可能 エネルギーの適切な導入方法や独居老人の見守り等に展開していきたい. 本実験に用いたシステムは，高度な処 理を実現する拡張性を保持しているため，大規模な導入まで対応が可能となる．ソフトウェアを除く機器類は汎 用的なものであり，導入コストは低い．コミュニティ内の善良な市民による電力消費の制御はスマートな社会を 実現するための第一歩となる.

\section{文献}

(1) SMART 研究会編, 地域分散エネルギー技術, 初版(2004), p.16, 海文堂.

(2)刑部真弘著, エネルギーのはなし, 朝倉書店, 初版(2011), p.94, p.100, 朝倉書店. 